\title{
The Relationship between Social Supports with Nursing Employee Attachment at Dr. R.M. Djoelham Hospital Binjai
}

\author{
Nini Sri Wahyuni', Rahma Fauzia ${ }^{2}$ \\ ${ }^{1}$ University of Medan Area, Medan, Indonesia \\ ${ }^{2}$ University of Medan Area, Medan, Indonesia \\ ninisriwahyuni.zul@gmail.com
}

\begin{abstract}
This article deals with the relationship between social supports with nursing employee attachment at Dr. R.M. Djoelham Hospital Binjai. This study aims to see the relationship between two variables and in the process of data analysis. This study uses numerical data or numbers that are processed by methodology, after the results are obtained then described by outlining the conclusions based on the numbers with the statistical method. The results shows that there is a significant positive relationship between social support and work attachment. This result is proven by the correlation coefficient $r_{x y}=0.377 ; p=0.000$ means $p<0.010$ means that the higher the social support, the higher the attachment of work to nurses and vice versa, if social support is obtained low, then the attachment of nurses work is also low. Thus, the hypothesis that has been proposed in this research is accepted. Social support has an effect of $14.2 \%$ on work attachment known from the determinant coefficient $r^{2}=$ $14.2 \%$. There are still $85.8 \%$ influence from other factors that affect work attachment, namely compensation, skills, optimism, self efficacy, and reciliency.
\end{abstract}

Keywords

social supports; nurse; work attachment; hospital

\section{Introduction}

In the current era of globalization, health technology is developing more rapidly along with the emergence of increasingly complex diseases. This requires hospitals to provide good and maximum services. Hospitals must have qualified medical personnel and be able to serve the community professionally.

RSUD Dr. RM Joelham Binjai is a state-class B hospital located on Jalan Sultan Hasanuddin 09 Binjai, North Sumatra. This hospital is included in the category of large regional general hospitals because there are 214 patient stays based on classes, more than each hospital in North Sumatra that has an average of 80 beds available. The number of doctors available is 106 doctors and the number of nurses is 184 nurses with details: 144 nurses with permanent status and 40 nurses with non-permanent status. The hospital is able to provide specialist medical services and limited subspecialists. The hospital also accommodates referral services from district hospitals.

Nurse is one of the medical staff in the hospital who is in charge of providing services in the form of care for patients and supporting patient health. Acoording to the laws of the Republic Indonesia number 23, 1992 nurses as those who have the ability and authority to carry out nursing actions based on knowledge possessed and obtained through nursing education. According to the Minister of Health of the Republic of Indonesia HK.02.02 / MenKes / 148/1/2010 regarding licensing and implementation of nurses' 
practices, a nurse is someone who has passed nursing education, both domestically and abroad in accordance with statutory provisions. A nurse is someone who has completed a nursing education program, is authorized in the country concerned to provide services, and responsible for improving health, preventing disease and providing services to patients (International Council Of Nursing, 1965). Nurses are workers who are always in every hospital that is responsible for the health of patients. Nurses in hospitals have duties on inpatient, outpatient or polyclinic services and emergency services. More and more hospitals which was founded, it will have an impact on the high demand for labor in the form of nurses from year to year, the indicator is that many D3 graduates in the field of nursing are spread in big cities in Indonesia. For nurses, becoming a D3 graduate in nursing is a path that has the potential to more quickly enter the workforce without undertaking long studies.

According to Sari (2020) Health services in Indonesia are implemented in stages, starting with basic health services by first-level health facilities. Second-level health services can only be provided upon referral from first-levelhealth services. Third level health services can only be provided on reference to second or first level health services, except in emergencies (Permenkes RI No. 001 of 2012).

Rational prescribing is an important element in achieving the quality of health services which is one indicator in patient safety in hospital (Lubis, 2020). A nurse who has a high level of attachment to a hospital has an understanding and concern for the hospital's operational environment, able to work together to improve the achievement of work units / organizations, Perryman and Hayday (in Indrianti, 2012). Schaufeli (2011) states that there are a number of professions that demand high work attachment, such as teachers, entrepreneurs, and of course nurses. The three professions are said to require a high work attachment because they have an element of unity that is equally capitalized on quality in service during work.

Schaufeli and Bakker (2010) define work attachment as "a positive state of mind related to work characterized by vigor, dedication and absorption.Vigor is characterized by a high level of energy and mental flexibility at work, a desire to invest effort in work, and remains steadfast despite face various difficulties; dedication refers to strong involvement in work and experiencing a sense of importance, enthusiasm and challenge to work; absorption is characterized by fully concentrating and feeling absorbed in his work, so that time passes quickly and it is difficult to break away from work. In short, employees who are bound have a high energy level and are enthusiastic about their work. Kahn (in Orford 2010) describes employees who are bound as physical, cognitive and emotional employees who are fully connected to their work roles. Based on a work attachment model called JD-R (Job DemandsResources) Model developed by Bakker and Demerouti (2008), it is seen that work attachment is influenced by job resources and personal resources. This model shows that job resources and personal resources individually or collectively predict employee work attachment. Job resources and personal resources have a positive impact on work attachment when demanded high employment (Bakker and Demerouti (2008).

Based on observations at the hospital of RSUD dr. RM Djoelham, there are some nurses who appear to be less friendly to patients when working such as more sitting and chatting with fellow nurses also seem less enthusiastic in working such as playing gadgets so that they appear to show less concentration in patients at work. It can be seen that work attachment nurses tend to be in the low category. Seeing this, external support is needed to support the nurses' attitude when working.

Sarafino (1994) states that "social support refers to providing comfort to others, caring for them, or appreciating them". A similar opinion was also expressed by House (in Cohen \& Syme 1985) which states that "social support is the existence of interpersonal interactions 
shown by providing assistance to other individuals, where the assistance is generally obtained from people who are meaningful to the individual concerned". Social support can be in the form of providing information, behavioral assistance, or material obtained from intimate social relationships that can make individuals feel cared for, valued and loved.

Social support affects the attachment of a nurse. The existence of adequate social support will increase self-esteem and personal control so that it raises social needs in increasing the maximum performance. When someone gets good social support, one's work attachment also increases. Based on observations at RSUD Dr. RM. Djoelham is known that the lack of social support for nurses such as the condition of superiors who are less protective and provide attention in the form of assistance to other nurses during the work process.

\section{Review of Literature}

\subsection{Definition of Nurse}

According to the Minister of Health of the Republic of Indonesia HK.02.02 / MenKes / $148 / 1 / 2010$ concerning licensing and implementation of nurse practice, a Nurse is someone who has passed nursing education, both domestically and abroad in accordance with statutory provisions. A nurse is someone who has completed nursing education programs, authorized in the country concerned to provide services, and are responsible for improving health, preventing disease and providing services to patients (international council of nursing, 1965).

According to Henderson (1980), nurses have a unique function of helping individuals who are both healthy and sick, from birth to death, so that they can carry out their daily activities independently, using their strength, willpower, or knowledge.

Based on the description above, a nurse is someone who has graduated from nursing education and has the ability and authority to perform nursing actions based on scientific fields that are owned and provide holistic and professional health services for healthy and sick individuals, nurses are required to meet the needs of patients including bio-psycho- socio and spiritual.

\subsection{Work Attachment}

Schaufeli and Bakker (2010) define work attachment as "a positive state of mind related to work characterized by vigor, dedication and absorption.Vigor is characterized by a high level of energy and mental flexibility at work, a desire to invest effort in work, and remains steadfast despite face various difficulties; dedication refers to strong involvement in work and experiencing a sense of importance, enthusiasm and challenge to work; absorption is characterized by fully concentrating and feeling absorbed in his work, so that time passes quickly and it is difficult to break away from work. In short, employees who are bound have a high energy level and are enthusiastic about their work.

Work attachment or what is often called attachment is stated by Arnold Bakker (2010) as the level of commitment and involvement that employees have towards their organization and the values in it that are seen in employees' positive attitudes towards the organization and the values contained therein.

In work attachment there is a high emotional and intellectual relationship between employees and their jobs, organizations, managers and coworkers, thus influencing employees to make more effort on their jobs. Increased energy, doing work that exceeds expectations, forms of adaptive or innovative behavior for company success are indicative of work attachment behavior.

According to Schiemann (2009), work attachment illustrates how far employees are willing to go beyond the minimum requirements of their role to provide additional energy or 
advocate (defend) their organization against other companies as a good place to work or invest. Bound employees will work harder and stay in the company longer, satisfy more customers and have a stronger positive influence on company results.

Young (in Kurniawati 2009) said that employee work attachment is a positive psychological state related to work which is characterized by a genuine desire to contribute to organizational success. In work attachment there is a high emotional and intellectual relationship between employees and their jobs, organizations, managers and coworkers, thus influencing employees to make more effort on their jobs. Increased energy, doing work that exceeds expectations, forms of adaptive or innovative behavior for company success are indicative of work attachment behavior.

Based on the description above it can be concluded that employee work attachment represents a positive psychological state of employment and organization as well as the values contained therein which give rise to a willingness to go beyond the minimum requirements of work and be reflected in a positive attitude to the organization through its best physical, cognitive performance contribution and emotions for organizational success. Definition of Social Support.

Diah (2020) states characteristics of society indirectly be factors that support or hinder the implementation of activities. Social status, social status of the majority of low-and middle-dyeing situation in the region is very isolated population with the majority of them are farmers and low level of formal education. Lack of education and the level of public awareness for healthy living and maintaining a healthy family to be a phenomenon that often occurs in people in very remote areas.

Sarafino (1994) states that "social support refers to providing comfort to others, caring for them, or appreciating them". A similar opinion was also expressed by House (in Cohen \& Syme 1985) which states that "social support is the existence of interpersonal interactions shown by providing assistance to other individuals, where the assistance is generally obtained from people who are meaningful to the individual concerned". Social support can be in the form of providing information, behavioral assistance, or material obtained from intimate social relationships that can make individuals feel cared for, valued and loved.

Social support is the support or assistance that comes from other people such as friends, family, neighbors, coworkers and others. Sarason, Sarason and Pierce (in Baron and Byrne, 2000) define social support as physical and psychological comfort provided by friends and family members.

Social support is interpersonal exchange where an individual provides assistance to other individuals. Social support is comfort, attention, appreciation, or assistance in other forms that individuals receive from others or from groups. Sarafino, (2002).

\section{Research Methods}

Research can be classified from various perspectives, including the analysis approach, the depth of analysis and the nature of the problem. Seen from the depth of the analysis, the study is divided into two kinds, namely qualitative research and quantitative research. Quantitative research aims to find whether there is a relationship between one variable with another variable.

Based on the depth of analysis, research is divided into descriptive and inferential research. Seen from the nature of the problem the research is divided into eight types, namely historical, descriptive, developmental, case / field research, correlational, comparative causal research, experimental research, and action research. "Correlational research aims to find whether there is a relationship between one variable with another, and if there is, some close 
relations and means there is a relationship" (Arikunto, 2006). In accordance with the title in this study, namely "The Relationship between Social Support with Nurse Work Attachment at RSUD dr. R.M Djoelham Binjai", then this study is included in the type of descriptive quantitative correlational research.

This is because this study aims to see the relationship between two variables and in the process of data analysis. This study uses numerical data or numbers that are processed by methodology, after the results are obtained then described by outlining the conclusions based on the numbers with the statistical method. The discussion of this research methodology will describe the identification of research variables, the perational definition of research variables, population and sampling techniques, data collection methods, validity and reliability of measuring instruments, and data analysis methods.

The following is the explanation of the variables in this study:

1. Independent variable (Variable X): Social Support

2. Dependent variable (Variable Y): Work attachment

Population can consist of subjects or objects that are characteristic, according to Sugiyono (2002) Population is a generalization area consisting of; an object or subject that has certain quantities and characteristics determined by the researcher to be studied, and then a conclusion is drawn. The entire research subject is the population, as for the population according to Arikunto (2002) In his book "Research Procedure for a Practical Approach" says that: Population is "Overall research subject". From the above understanding, the authors can draw the conclusion that the population is the total number of samples. The population in this study were nurses at RSUD dr. R.M Djoelham Binjai, namely 144 permanent nurses.

According to Sugiyono (2010) the sample is part of the number and characteristics possessed by the population, the sample taken must be representative or represent the population. The subjects of this study were 100 permanent nurses. Thus the researchers took the data by population research methods from research subjects by taking into account the characteristics mentioned above, namely permanent nurses of 100 people.

An instrument is said to be valid if it has measured what should be measured. The instrument is said to be valid if it reveals the data of the variables studied appropriately. The validity test technique used in this study is Product Moment Correlation.

The product moment correlation formula is as follows:

$r_{z y}=\pi r^{2}=\frac{\mathrm{n} \cdot(\Sigma \mathrm{XY})-(\Sigma \mathrm{X}) \cdot(\Sigma \mathrm{Y})}{\sqrt{\left[n X^{2}-\left(\Sigma X^{2}\right)^{2} V n \Sigma Y^{2}-(\Sigma \mathrm{Y})^{2}\right]}}$

Information:

$r_{X Y}:$ Correlation coefficient between variable $\mathrm{X}$ and variable $\mathrm{Y}$.

$\Sigma X Y:$ The number of times the product of each $\mathrm{X}$ with every $\mathrm{Y}$.

$\Sigma X \quad:$ The total number of subjects for each item.

$\Sigma Y \quad$ : Total number of items on the subject.

$\Sigma \quad$ : Total squared score $\mathrm{X}$.

$\Sigma \quad$ : Number of squares of Y score.

$\mathrm{N} \quad$ : Number of subjects.

In accordance with the title of the study which aims to determine whether there is a relationship between social support and work attachment, the data analysis method that will be used to test hypotheses in this study is the product moment correlation technique from Karl Pearson. 
$r_{x y}=\pi r^{2}=\frac{\mathrm{n} \cdot(\Sigma \mathrm{XY})-(\Sigma \mathrm{X}) \cdot(\Sigma \mathrm{Y})}{\sqrt{\left[n X^{2}-\left(\Sigma X^{2}\right)^{2} 3 n \Sigma Y^{2}-(\Sigma \mathrm{Y})^{2}\right]}}$

Information:

$r_{X Y}:$ Correlation coefficient between variable $\mathrm{X}$ and variable $\mathrm{Y}$.

$\Sigma X Y:$ The number of times the product of each $X$ with every $Y$.

$\Sigma X \quad:$ The total number of subjects for each item.

$\Sigma Y \quad$ : Total number of items on the subject.

$\Sigma \quad$ : Total squared score $\mathrm{X}$.

$\Sigma \quad$ : Number of squares of $\mathrm{Y}$ score.

$\mathrm{N} \quad$ : Number of subjects.

\section{Discussion}

The scale of social support is based on forms of social support, namely emotional support, appreciation support, instrumental support, information support, and social network support. The social support scale consists of 40 items consisting of 31 favorable items and 9 unfavorable items with four alternative answers namely strongly agree (SA), agree (A), disagree (D), and strongly disagree (SD). These items have scores as follows: Favorable items with strongly disagree answers (SD) are given a score of 1, disagree answers (D) are given a score of 2, agree answer (A) is given a score of 3, a strongly agree answer (SA) is given a score 4 . While unfavorable items will be given a score of 4 for strongly disagree answers (SD), a score of 3 for disagree answers (D), a score of 2 for agree answers (A), and a score of 1 for strongly agree answers (SA). The use of four alternative answers to avoid responses in the middle, especially for those who are doubtful of the answers given. Distribution of social support scale items can be seen in table 1.

Table 1. Distribution of Social Support Scale Items before Trial

\begin{tabular}{|c|l|l|c|c|c|}
\hline \multirow{2}{*}{ No } & Forms & \multicolumn{1}{|c|}{ Indicators } & \multicolumn{2}{|c|}{ Item Numbers } & \multirow{2}{*}{ Total } \\
\cline { 3 - 5 } 1 & $\begin{array}{l}\text { Emotional } \\
\text { support }\end{array}$ & $\begin{array}{l}\text { Expression of empathy } \\
\text { and caring }\end{array}$ & $1,13,19,24,28,33$ & 7,40 & 8 \\
\hline 2 & $\begin{array}{l}\text { Award } \\
\text { support }\end{array}$ & $\begin{array}{l}\text { Expressions of } \\
\text { appreciation and } \\
\text { encouragement to } \\
\text { move forward }\end{array}$ & $\begin{array}{l}2,3,8,9,14,15,20, \\
32,29,25\end{array}$ & 10,36 & 12 \\
\hline 3 & $\begin{array}{l}\text { Instrumental } \\
\text { support }\end{array}$ & Real help (material) & $4,16,21,34$ & & 4 \\
\hline 4 & $\begin{array}{l}\text { Information } \\
\text { Support }\end{array}$ & $\begin{array}{l}\text { Advice and } \\
\text { suggestions received }\end{array}$ & $5,11,17,22,26,30$ & $18,37,38$ & 9 \\
\hline 5 & $\begin{array}{l}\text { Social } \\
\text { Network } \\
\text { Support }\end{array}$ & $\begin{array}{l}\text { A sense of } \\
\text { togetherness and } \\
\text { friendship }\end{array}$ & $6,12,27,31,35$ & 39,23 & 7 \\
\hline
\end{tabular}

Work attachment scale is arranged based on aspects of attachment, namely vigor, absorption, and dedication. The work attachment scale consists of 40 items consisting of 24 favorable items and 16 unfavorable items with four alternative answers namely strongly agree 
(SA), agree (A), disagree (D), and strongly disagree (SD). These items have scores as follows: Favorable items with strongly disagree answers (SD) are given a score of 1, disagree answers (D) are given a score of 2, an agree answer (A) is given a score of 3, a strongly agree answer (SA) is given a score 4. While unfavorable items will be given a score of 4 for strongly disagree answers (SD), a score of 3 for disagree answers (D), a score of 2 for agree answers (A), and a score of 1 for strongly agree answers (SA). The use of four alternative answers to avoid responses in the middle, especially for those who are doubtful of the answers given. The distribution of work attachment scale items can be seen in table 2 .

Table 2. Distribution of Work Attachment Scale Items before Trial

\begin{tabular}{|c|c|c|c|c|c|}
\hline \multirow[b]{2}{*}{ No } & \multirow[b]{2}{*}{ Aspects } & \multirow[b]{2}{*}{ Indicators } & \multicolumn{2}{|c|}{ Item Numbers } & \multirow[b]{2}{*}{ Total } \\
\hline & & & Favorable & Unfavorable & \\
\hline 1 & Vigor & High energy level & $\begin{array}{c}1,4,7,10,19,22, \\
27,39\end{array}$ & $5,8,13,26,29,32$ & 14 \\
\hline 2 & Absorption & $\begin{array}{l}\text { Totality and } \\
\text { happiness while } \\
\text { working }\end{array}$ & $\begin{array}{c}11,12,14,17,23 \\
, 30,33,35,37\end{array}$ & $2,16,20,25,28,40$ & 15 \\
\hline 3 & Dedication & $\begin{array}{l}\text { Dedicated while } \\
\text { working }\end{array}$ & $\begin{array}{c}3,6,9,15,18,21, \\
24\end{array}$ & $31,34,36,38$ & 11 \\
\hline \multicolumn{5}{|c|}{ Total } & 40 \\
\hline
\end{tabular}

Based on social support scale research data, the number of items tested was 40 items and 32 items met the rix discrimination index $\geq 0.3$. Azwar (2007) states that the criteria based on total item correlation are usually used to limit rix $\geq 0.3$. All items that reach a correlation coefficient of at least 0.3 are considered satisfactory. A total of 8 items are deemed invalid, namely item number $4,9,13,22,24,26,31$, and 36 . The following is a table of items distribution of valid items on the social support scale after the trial.

Table 3. Distribution Table of Social Support Scale Items after Trial

\begin{tabular}{|c|c|c|c|c|c|c|c|}
\hline \multirow[t]{3}{*}{ No } & \multirow[t]{3}{*}{ Forms } & \multirow[t]{3}{*}{ Indicators } & \multicolumn{4}{|c|}{ Item Numbers } & \multirow[t]{3}{*}{ Total } \\
\hline & & & \multicolumn{2}{|c|}{ Favorable } & \multicolumn{2}{|c|}{ Unfavorable } & \\
\hline & & & Valid & Invalid & Valid & Invalid & \\
\hline 1 & $\begin{array}{l}\text { Emotional } \\
\text { support }\end{array}$ & $\begin{array}{l}\text { Expression of } \\
\text { empathy and caring }\end{array}$ & $\begin{array}{c}1, \\
19,28,33\end{array}$ & 13,24 & 7,40 & - & 8 \\
\hline 2 & $\begin{array}{l}\text { Award } \\
\text { support }\end{array}$ & $\begin{array}{l}\text { Expressions of } \\
\text { appreciation and } \\
\text { encouragement to } \\
\text { move forward }\end{array}$ & $\begin{array}{c}2,3,8,14, \\
15,20,32, \\
29,25\end{array}$ & 9 & 10 & 36 & 12 \\
\hline 3 & $\begin{array}{l}\text { Instrumental } \\
\text { support }\end{array}$ & $\begin{array}{l}\text { Real help } \\
\text { (material) }\end{array}$ & $16,21,34$ & 4 & - & & 4 \\
\hline 4 & $\begin{array}{l}\text { Information } \\
\text { Support }\end{array}$ & $\begin{array}{l}\text { Advice and } \\
\text { suggestions } \\
\text { received }\end{array}$ & $\begin{array}{c}5,11,17,3 \\
0\end{array}$ & 22,26 & $\begin{array}{c}18,37 \\
38\end{array}$ & - & 9 \\
\hline 5 & $\begin{array}{l}\text { Social } \\
\text { Network } \\
\text { Support }\end{array}$ & $\begin{array}{l}\text { A sense of } \\
\text { togetherness and } \\
\text { friendship }\end{array}$ & $\begin{array}{c}6,12,27,3 \\
5\end{array}$ & 31 & 39 & - & 7 \\
\hline \multicolumn{3}{|c|}{ Total } & 24 & 7 & 8 & & 40 \\
\hline
\end{tabular}


After testing the validity of items, then proceed with reliability analysis. The reliability testing technique of social support scale using alpha cronbach and obtained a reliability of $=$ 0.951 . The results of the calculation of the reliability of the research data scale can be seen in the following table:

Table 4. The Reliability Test Results for the Social Reliability Statistics Support Scale

\begin{tabular}{|c|c|}
\hline Cronbach's alpha & Number of Item \\
\hline .951 & 40 \\
\hline
\end{tabular}

\subsection{Work Attachment Scale}

Based on research data on work attachment scale, the number of items tested was 40 items and there were 37 items that met the discrimination index rix $\geq 0.3$. Azwar (2007) states that the criteria based on total item correlation are usually used to limit rix $\geq 0.3$. All items that reach a correlation coefficient of at least 0.3 are considered satisfactory. A total of 3 items are deemed invalid, namely item number 1, 17 and 34 . The following is a table of items distribution valid items from the work attachment scale after the trial.

Table 5. Distribution Table of Work Attachment Scale Items after Trial

\begin{tabular}{|c|c|c|c|c|c|c|c|}
\hline \multirow[t]{3}{*}{ No } & \multirow[t]{3}{*}{ Aspects } & \multirow{3}{*}{ Indicators } & \multicolumn{4}{|c|}{ Item Numbers } & \multirow[t]{3}{*}{ Total } \\
\hline & & & \multicolumn{2}{|c|}{ Favorable } & \multicolumn{2}{|c|}{ Unfavorable } & \\
\hline & & & Valid & Invalid & Invalid & Gugur & \\
\hline 1 & Vigor & $\begin{array}{l}\text { High energy } \\
\text { level }\end{array}$ & $\begin{array}{l}4,7,10,19 \\
22,27,39\end{array}$ & 1 & $\begin{array}{c}5,8,13,26, \\
29,32\end{array}$ & - & 14 \\
\hline 2 & Absorpsion & $\begin{array}{l}\text { Totality and } \\
\text { happiness }\end{array}$ & $\begin{array}{c}11,12,14, \\
23,30,33, \\
35,37\end{array}$ & 17 & $\begin{array}{c}2,16,20,25 \\
, 28,40\end{array}$ & - & 15 \\
\hline 3 & Dedication & $\begin{array}{l}\text { Dedicated } \\
\text { to work }\end{array}$ & $\begin{array}{l}3,6,9,15, \\
18,21,24\end{array}$ & - & $31,36,39$ & 34 & 11 \\
\hline \multicolumn{3}{|c|}{ Total } & 22 & 2 & 15 & 1 & 40 \\
\hline
\end{tabular}

After testing the validity of items, then proceed with reliability analysis. The reliability test technique of work attachment scale using Cronbach alpha and obtained a reliability of $=$ 0.959. The results of the calculation of the reliability of the research data scale can be seen in the following table:

Table 6. Reliability Test Results of Work Attachment for Reliability Statistics

\begin{tabular}{|c|c|}
\hline Cronbach's Alpha & Number of Items \\
\hline .959 & 40 \\
\hline
\end{tabular}

Normality test is carried out to determine whether each research variable has spread normally. To conduct the distribution normality test the Kolmogorov-Smirnov test was used. If $p>0.05$ then the distribution is normal and if $p<0.05$ then it is declared abnormal. The normality of social support and work attachment variables can be seen in table 7 .

Table 7. Summary of Calculation Results for the Distribution Normality Test

\begin{tabular}{|l|c|c|c|c|c|}
\hline \multicolumn{1}{|c|}{ Variable } & Average & SD & K-S & P & Information \\
\hline Social support & 596.700 & 707.400 & 0.867 & 0.440 & Normal \\
\hline Work attachment & 585.000 & 801.703 & 0.673 & 0.756 & Normal \\
\hline
\end{tabular}


Information:

Average $=$ Average value

$\mathrm{K}-\mathrm{S}=$ Kolmogorov-Smirnov coefficient

$\mathrm{SB} \quad=$ Standard Deviation (Standard Deviation)

$\mathrm{P} \quad=$ Error solving opportunity

Can be accepted normally distributed if $\mathrm{p}>0.05$. From the Kolmogorov-Smirnov test results in the table it can be concluded as follows:

1) Social support variable is normal distribution with $\mathrm{K}-\mathrm{S}$ value $=0.867$ with $\mathrm{p}=0.440$ or $\mathrm{p}>$ 0.05 .

2) Work attachment variable shows normal distribution with $\mathrm{K}-\mathrm{S}$ value $=0,673$ with $\mathrm{p}=$ 0,756 or $\mathrm{p}>0,05$.

a. Test Linearity Relations

Linearity test to request data distribution assistance Research in social support and work attachment for linear relationships. To test it used the $\mathrm{F}$ (Anova) test technique. If $\mathrm{p}>0.05$ then the distribution is declared not linear and if $\mathrm{p}<0.05$ then the distribution is declared linear. The linearity of social support and attachment variables can be seen in Table 8 .

Table 8. Summary of Calculation Results for Linearity Tests

\begin{tabular}{|c|c|c|c|}
\hline Correlational & F Differ & p Differ & Information \\
\hline $\mathrm{X}-\mathrm{Y}$ & 19.833 & 0.000 & Linier \\
\hline
\end{tabular}

Information:

$\mathrm{X} \quad=$ Social Support

$\mathrm{Y} \quad=$ Work Attachment

F Differ $=$ Linearity coefficient

P Differ $=$ Proportion of errata chances

1. Calculation Results of Person Product Moment Data Analysis

Based on the results of the analysis with the Product Moment Relationship Analysis Method, it is known that there is a significant positive relationship between social support and work attachment, where $\mathrm{p}=0.000 ; \mathrm{p}<0.05$. it means that the more positive the social support, the higher the attachment to work. Or conversely, the more negative the social support the lower the work attachment of nurses. Thus, the hypotheses that have been proposed in this study, are declared "accepted". The following table is the result of calculation of Person Product Moment data analysis:

Table 9. Summary of $r$ Person Product Moment Calculation Results

\begin{tabular}{|c|c|c|c|c|c|}
\hline Statistics & Koefisien $\left(\boldsymbol{r}_{\boldsymbol{x y}}\right)$ & Koefisien Det. $\left(\boldsymbol{r}^{2}\right)$ & $\mathbf{p}$ & BE\% & Information \\
\hline $\mathrm{X}-\mathrm{Y}$ & 0.377 & 0.142 & 0.000 & 14.2 & $\mathrm{~S}$ \\
\hline
\end{tabular}

Information:

$\mathrm{X} \quad=$ Social Support

$\mathrm{Y} \quad=$ Work Attachment

$r_{x y} \quad=$ Coefficient of the relationship between $\mathrm{X}$ and $\mathrm{Y}$ 


$$
\begin{array}{ll}
r^{2} & =\text { Determinant coefficient } \mathrm{X} \text { with respect to } \mathrm{Y} \\
\mathrm{P} & =\text { Odds of error } \\
\mathrm{BE} \% & =\text { Weight of effective contribution } \mathrm{x} \text { to } \mathrm{Y} \text { in percent } \\
\text { Ket } & =\text { Very significant at } 1 \% \text { significance level } \mathrm{p}<0.010
\end{array}
$$

2. Calculation Results of Hypothetical Mean and Empirical Mean

a. Hypothetical Mean / Average Value

For social support variables, the number of valid items is 32 items formatted with a Likert scale in 4 answer choices, then the hypothetical mean is $((32 \times 1)+(32 \times 4)): 2=80$. Then for the variable attachment number 37 valid items are formatted with a Likert scale in 4 answer choices, then the hypothetical mean is ((37 X 1) + (37 X 4)): $2=92.5$.

Based on data analysis, as seen from the distribution normality test analysis it is known that, the empirical mean of social support variables is 59.6700 while for work attachment variables, the empirical mean is 58.5000.

In an effort to find out the conditions of social support and work attachment, it is necessary to compare the mean / empirical average value with the hypothetical mean / mean value by observing the amount of SB or SD numbers of each variable. For social support variables the SB or SD value is 7.07400, while for the work attachment variable is 8.01703.

From the amount of SB or SD numbers, then for social support variables, if the mean / average hypothetical value <mean / empirical average value, where the difference exceeds the number one SB / SD, then it is stated that individual social support is high and if hypothetical mean / mean <empirical mean / mean or hypothetical mean / mean empirical mean / mean value / hypothetical mean difference and empirical mean / mean value> SD, it is stated that individual social support is classified as moderate. And if the mean / hypothetical mean value> mean / empirical average value, where the difference exceeds the standard deviation / Standard Deviation numbers, then it is stated that individual social support is low.

Furthermore, for the work attachment variable, if the hypothetical mean / mean < empirical mean / mean value, where the difference exceeds one SB / SD number, then it is stated that the individual work attachment is high and if the mean / hypothetical mean value < mean / empirical mean value / mean / hypothetical mean value $>$ mean / empirical average value with mean difference / hypothetical mean value and empirical mean / mean value > SD, then it is stated that individual work attachment is classified is on. And if the mean / hypothetical mean value > mean / empirical average value, where the difference exceeds the standard one deviation / Standard Deviation, then it is stated that individual work attachment

\begin{tabular}{|c|c|c|c|c|c|}
\hline \multirow[b]{2}{*}{ Variable } & \multicolumn{2}{|c|}{ SD } & \multicolumn{2}{|c|}{ Mean } & \multirow[b]{2}{*}{ Information } \\
\hline & Hypothetical & Empirical & Hypothetical & Empirical & \\
\hline $\begin{array}{l}\text { Social } \\
\text { support }\end{array}$ & 26,66 & 7,074 & 80 & 59,67 & Low \\
\hline $\begin{array}{l}\text { Work } \\
\text { attachment }\end{array}$ & 30,83 & 8,01703 & 92,5 & 58,5 & Low \\
\hline
\end{tabular}
is classified as low. A complete picture of the comparison of mean / hypothetical mean values with empirical mean / mean values can be seen in the table below.

Table 10. Calculation Results of Hypothetical Average and Empirical Average Values

The results of the study on 100 samples of nurses in RSUD Dr.R.M Djoelham Binjai showed that there was a relationship between social support and work attachment. It is known based on the results of the analysis with the product moment correlation analysis method, that 
there is a significant positive relationship between social support and work attachment of nurses at Dr.R.M Djoelham Binjai Hospital. Reviewing the correlation coefficient where = $0.377 ; p=0,000<0.050$. This means that the higher the social support, the higher the work attachment of nurses. Or conversely the lower the social support, the lower the work attachment of nurses. Thus, the hypotheses that have been proposed in this study, are declared "accepted". The results of this study are in line with the results of Monica's study (2012) "when someone gets good social support can prevent work stress so that the person is more adaptive in overcoming problems". The more a person feels supported, it will have an impact on increasing enthusiasm and high dedication in accordance with work attachment factors according to Bakker, (2008).

Monica's research (2012) which also examined the relationship of social support and the meaning of work as a vocation with work attachment in Menur General Hospital, obtained a positive correlation of 0.651 with an effective contribution of $42.4 \%$. When someone has high social support and interpret their work as a vocation, the nurse will show high morale and dedication and spend a lot of time in their work without feeling burdened. In this case social support and the meaning of work as a vocation are related to work attachment. These results indicate that there is a positive relationship between social support and work attachment to nurses and further strengthen the results of this study.

In this study social support had an effect of $14.2 \%$ on work attachment, known from the determinant coefficient $r^{2}=14.2 \%$. There are still $85.8 \%$ influence from other factors that affect work attachment, namely compensation, skills, optimism, self efficacy, and reciliency. Reviewing the results of research through empirical data on work attachment $=58.5000$ and social support 59.6700. In addition, the hypothetical mean value of work attachment $=92.5$ and social support 80. From these results it is known that social support and work attachment to nurses in Dr.RM.Djoelham Binjai Regional Hospital are classified as low.

\section{Conclusion}

There is a significant positive relationship between social support and work attachment. This result is proven by the correlation coefficient $r_{x y}=0.377 ; \mathrm{p}=0.000$ means $\mathrm{p}<0.010$ means that the higher the social support, the higher the attachment of work to nurses and vice versa, if social support is obtained low, then the attachment of nurses work is also low. Thus, the hypothesis that has been proposed in this research is accepted.

Social support has an effect of $14.2 \%$ on work attachment known from the determinant coefficient $r^{2}=14.2 \%$. There are still $85.8 \%$ influence from other factors that affect work attachment, namely compensation, skills, optimism, self efficacy, and reciliency.

In this study found low work attachment and social support in nurses in Dr.RM Djoelham Binjai Regional Hospital with an empirical mean value obtained was 59.6700 and a hypothetical mean was 80 for social support and for work attachment was obtained empirical mean: 58.5000 and the hypothetical mean was 92.5 .

\section{References}

Arikunto, Suharsimi. (2003). Dasar-Dasar Statistika.Bandung: Alfa Beta.

Azwar, S. (2005). Metode Penelitian. Yogyakarta: Pustaka Pelajar

Azwar, S. (2005). Penyusunan Skala Psikologis. Yogyakarta : Pustaka Pelajar

Bakker, A. B., \& Despoina, X. (2009). The Crossover of daily work attachment: Test of an actor-partner interdependence model. Journal of Applied Psychology, 94, (6), 1562- 
1571. Preliminary manual, version 1. Occupational health psychology unit Utrecht University.

Bakker, A.B., Schaufeli, W. (2003). Utrecht Work Angagement Scale.Preliminary Manual. Holland. Utrecht University

Bakker, A. B., \& Wilmar, S. (2003). Utrecht work attachment scale (UWES).

Bakker, A.B., Leiter, M.P. (2010). Work Angagement. A Handbook of Essential Theory and Research. New York. Psikologi Press

Bakker, Schaufeli, Leiter, \& Taris. (2008). Work attachment: An emerging

Baron, A.R, Bryrne, Donn. (2003) Psikologi Sosial Jilid 1.Jakarta. Erlangga

Cohen, S., \& Syme, S. L. (1985).Social Support and Health.Florida: Academic Press.Inc.

Deeter, D.R., dan Ramsey, RP., (1997). Considering Source and Types of Social Support : A Psychometric Evaluation of the House and Wells (1978)Instrumen. Journal of Personal Selling and Sales Management, Vol. XVII, No.1.1997.

Diah, Y., Lubis, Z., and Sanusi, S. R. (2020). The Health Worker Motivation and Competence in the Utilization of $\mathrm{MCH}$ Handbook In Bireuen District. Britain International of Exact Sciences (BIoEx) Journal, 286-291.

Gunarsa, SD., \& Gunarsa Y.S (1995). Psikologi Perawatan. Jakarta: BPK. Gunung Mulia.

Hasibuan, Malayu S.P. (2009). Manajemen Sumber Daya Manusia. Jakarta: Bumi Aksara.

Henderson, (1980).Etika dan Hukum Keperawatan. Jakarta. TIM

Indrianti, R., dan Dr. Cholichul, H. (2012).Hubungan antara Modal Psikologis dengan Keterikatan Kerja pada Perawat di Instalasi Rawat Inap Rumah Sakit Jiwa Menur Surabaya.Universitas Airlangga Surabaya. Jurnal Psikologi Industri dan Organisasi Vol.1 No.2 Juni

Iskandar,Dr.MPd.(2008).Metodologi penelitian pendidikan dan sosial. Ciputat.jakarta.GP press

Kozier, (1991) .Etika dan Hukum Keperawatan. Jakarta. TIM

Kurniawati, I.D (2014). Masa Kerja dengan Jobattachment pada Keryawan. Jurnal Ilmiah Mahasiswa Universitas Muhammadiyah Malang. Vol. 02 No. 02.

Lubis, F. I., Zulfendri and Jumirah. (2020). Collaboration the Role of Doctors and Pharmacers in Rational Preparation in Rantauprapat Hospital, Constraints and Its Efforts. Britain International of Exact Sciences (BIoEx) Journal, 19-28.

Monica, D.P. (2012)Hubungan antara Dukungan sosial dan Makna Kerja Sebagai Panggilan dengan Keterikatan Kerja. Unversitas Surabaya. Jurnal Ilmiah Universitas surabaya Vol.1 no.1

Ni'mah, A. (2014). Hubungan Antara Dukungan Sosial Dengan Self Efficacy Dalam Menyelesaikan Skripsi Pada Mahasiswa Jurusan Bimbingan Dan Konseling.Universitas Negeri Semarang.

Orford.W.A. Psichological Condition of Personal Attachment and Disattachment at Work. Academi of Management Journal of Business and Management. 2010.Vol.5 No.12

Puspita, M.D. (2012). Hubungan antara Dukungan Sosial dan Makna Kerja Sebagai Panggilan (Calling) dengan Keterikatan Kerja. Universitas Surabaya.Vol.1No.1.http://journal.ubaya.ac.id/index.php/jimus/article/viewFile/40/35

Ridwan, (2003). Dasar-Dasar Statistika.Bandung : Alfa Beta.

Riduwan.(2009). Metode dan teknik Menyusun Proposal Penelitiaan. Bandung. Alfa beta.

Riduwan and Tita L.(1997).Dasar-dasar statistika. Bandung. Alfa beta.

Sarafino, E.P. (1994). Health Psychology: Biopsychosocial and Interaction. United States of America: John Wiley \& Sons, Inc. 
Sari, F. N., Zulfrendi, and Sanusi, S. R. (2020). Referral Demand of Patients in Pantai Cermin Public Health Center Langkat. Britain International of Humanties and Social Sciences (BIoHS) Journal, 314-320.

Schaufeli, W.B. \& Bakker, A.B. 2004. "Job demands, job resources, and their relationship with burnout and attachment: a multi-sample study". Journal organizational behavior. Vol 25, pp 293-315.

Schiemann, W.A (2011).Aligment Capability Attachment.jakarta:PPM Manajemen

Siagian, P. Sondang. (2014). Manajemen Sumber Daya Manusia. Jakarta: Bumi Aksara.

Stanley, (2002).Affective, continuance, and normative commitment to the organization:A meta analysis of antecedents,correlates, and consequences. Journal of Vocational Behavior, 61, 20]52.

Steers, R.M., (1980). Efektivitas Organisasi (Kaidah Tingkah Laku). Jakarta. Erlangga

Sugiyono.(2003). Dasar-Dasar Statistika.Bandung : Alfa Beta.

Sugiyono.(2004). Metode Penelitian Bisnis. Bandung : Alfabeta.

Wibowo, R.F (2014). Self Efficacy dan Prokrastinasi pada mahasiswa Fakultas Psikologi Universitas Surabaya.Jurnal Ilmiah Mahasiswa Universitas Surabaya. Vol.3 No.1 